\title{
Evolution of Ancient Alphabet to Modern Greek, Latin and Cyrillic Alphabets and Transcription between Them
}

\author{
Xiangning Zhang ${ }^{1, \text { a, * }}$, and Ruolin Zhang ${ }^{2, b}$ \\ ${ }^{1}$ Department of Pathophysiology, Guangdong Medical University, 1 Xincheng Avenue, Songshan Lake \\ Scientific and Industrial Park, Dongguan, Guang Dong, People’s Republic of China \\ ${ }^{2}$ Undergraduate Program, Department of English, Guangzhou University Sontan College, Zhuchun Street, \\ Zengcheng, Guangzhou, Guang Dong, People’s Republic of China \\ a email: zhangxn_2006@126.com, bemail: 461696469@qq.com, \\ *Corresponding author
}

Keywords: Alphabet, Phoenicia, Greece, Roman Empire, Slavian, European Union,

\begin{abstract}
The elements of alphabet tables reflect the phonetics of different languages. The earliest alphabet was invented by Phoenician in 200 millennium BCE, and was spread by businessmen from there; it was modified to form Greek alphabet, and Greek alphabet was introduced to Roman Empire and a new script, Latin alphabet was formed and spread in western part of Europe. Cyrillic alphabet adapted from Greek alphabet spread with Eastern Orthodox in eastern and southern Europe, and replaced Arabic scripts in North and Central Asian when inhabitants there were converted to Russian Orthodox. The modification of alphabets take place in accordance with the phonetics of the languages which they write, and also in keeping up with the development of information technology.
\end{abstract}

\section{Introduction}

The element of an alphabet table is dependent on the phonetics of a language; for close languages, the alphabets are similar. An example, the Latin alphabets of Scandinavian languages contain three additional letters with diacritic signs; each pair of letters from the two groups functions the same albeit they are not the same in written form in Swedish(ä, å, ö), Danish and Norwegian (æ, å, ø) languages[1, 2, 3].

The region where Greek, Latin and Cyrillic alphabets are used covers a large area of Eurasian continent. They can trace their origin to Phoenician alphabet, which was a descendant of ancient Egyptian hieroglyphs. During first millennium BCE, Phoenician people inhabited today's Syria, along the coastline of Mediterranean. During the era around 1050 BC, Phoenician alphabet was invented; and is the oldest verified alphabet [4]. It is an abjad, a type of writing system whose symbols are consonants, leaving the reader to supply the appropriate vowel [5]. The Phoenician alphabet consisted of 22 letters, all consonants, with matres lectionis used for some vowels in certain late varieties. It was used for the writing of Phoenician, a Northern Semitic language, used by the civilization of Phoenicia. The original signs corresponded to some words, for example, ox (“aleph"), house ("bet”), and camel ("gimel”).

Most likely as a consequence of phonetic changes in North Semitic languages, the Aramaeans people reused certain letters in the alphabet to represent long vowels. Its derivative, Aramaic eventually became the script of many nations in the Middle East. One important example is the square Hebrew script. Aramaic alphabet also evolved into the Arabic script [6],

Phoenician alphabet was adopted by the Greeks, and vowels were added to it [7]. It was modified and used to write Greek language, becoming historic and Modern Greek alphabet, and comparison of the two alphabet table suggested the development of letter in thousands of year; the order of the elements on the tables remains almost the same.

Greek alphabet was introduced to Roman Empire, and was modified as Latin alphabet which spread to the western part of Europe with Christianity, and replaced different alphabets like Runic 
used by Germanic languages. It was also used in the region of today's Baltic countries, and Slavic countries where Catholicism was adopted, like Croatia, Czech, Poland, Slovakia, and Slovenia. When Latin alphabets entered the Slavic countries in Central Europe, the number of the letters including modified ones on the alphabet tables was the same as the old Slavic ones; with additions to the letters of the basic Latin script $[8,9]$.

When Eastern Orthodox spread to east- and southward during Byzantine era, the further spread of Cyrillic alphabet to Asia was accompanied by submission of the Turkic nations in Urals and Siberia to Czar Rule, and converted to Russian Orthodox; the local scripts were gradually replaced by Cyrillic alphabet. With their incorporation to the Soviet Union, the Arabic script was abandoned by Central Asian nations [10,11]. Although Latin alphabet and other scripts for example, Georgian script existed with the Soviet boundary, Cyrillic alphabet became the sole script in Russia after the collapse of the Soviet Union according to the the Russian constitution.

The European Union (EU) was formed on the basis of 12 founding members from European Community in 1992[ 12]; Greece was the $10^{\text {th }}$ country o join the European Communities, precursor to EU and has been part of the Eurozone since 2001[13]. Greek alphabet was the only non-Latin script of the EU, prior to admission of Bulgaria as a full member of EU in 2007[14, 15].

\section{Transcription of Greek, Latin and Cyrillic Alphabets}

The comparison between different alphabets reveals phonetic difference of different languages. The Greek alphabets contain 24 letters, they include 7 vowels: the letters of A, E, I, O, U are vowels, but there are duplicates of equivalent of $\mathrm{E}$ (epsilon and eta) and $\mathrm{O}$ (omicron and omega) in Greek language; 12 consonants: B(beta), G(gamma), D (delta), Z (zeta), K(kappa), L (lambda), M (mu), $\mathrm{N}(\mathrm{nu}), \mathrm{P}(\mathrm{pi}), \mathrm{R}$ (rho), $\mathrm{S}$ (sigma), $\mathrm{T}(\mathrm{tau})$, and 5 dual consonants (three are only transcribed to be digraphs): $\Theta$ ( theta), X (ksi), F(phi), X (chi or khi), $\Psi$ (psi).

The Russian alphabet was formed based on the early Cyrillic alphabet developed during the 9th century $\mathrm{AD}[16]$, created with the spread of Eastern Orthodox southward and eastward[17, 18]. There are 33 letters in modern Russian alphabet. It is similar with Greek, with additional letters supplemented after the phonetically related ones, reflecting a more complicated phonetics of the Russian language.

\subsection{On Transcription between Greek, and Latin alphabets}

Both Greek and Latin alphabet tables begin with A and B; The Latin letter "C " comes from the Semitic " $G$ ", with the name "gimel" meaning camel [19]. The original form of " $C$ ", therefore was the Greek later " $G$ ". It represented / $\mathrm{k}$ / when Latin alphabet was introduced into Britain. But during the course of the Old English period by the tenth century, / $\mathrm{k} /$ before front or soft vowels, e.g. $\mathrm{i}$ and e, were palatalized, having changed to a sound similar with ch in cheese. By the end of the thirteenth century both in France and England, this sound de-affricated to $/ \mathrm{s} /[20]$. $\Theta, \theta$ is equivalent or similar with Runic b; p, ð which became th- in modern European languages, like in "futhark"[21]. There was no letter F in Greek, but there is $\mathbf{F}$ after Y(upsilon), equivalent with letter $\mathrm{U}$; the letter $\mathrm{H}$ is absent in Greek alphabet, but there is X equivalent with ch or kh, which appear in German Achlaut and Russian words like Тихий(tikhiy; quiet) and Захаров(Zakharov) and so on . The letter is placed after $\mathbf{F}$ (phi). "J" in Latin alphabet is a short I, and in German and Italian it serves as Y as in Yankee . From K to N, the letters are the same in Latin, Greek and Russian or Cyrillic alphabets. After N, there is a Greek letter $\mathbf{X}(\mathrm{X})$, such words in English like " xenograft"with consonant $\mathrm{x}$ in the beginning, are exclusively loaned from Greek. From $\mathrm{O}$ to $\mathrm{U}$, the letters are almost the same in the three alphabet tables, but in Latin letters there is a Q which constantly appears before " $U$ " to function as "ku". Some words of Arabic and other languages contain a sound of " $k$ " in the end. When they enter English, the letter "q" could also appears separately, e.g Iraq. Y(upsilon) in Greek is equivalent with $U$ in English, but it sounds more like "Ü ” in German "Über " and "u"in French "superieur". Letter V is phonetically absent in Greek like in many languages, e.g. Chinese and Japanese. In some languages using Latin alphabet, the letter "W" was designed as "double V" which was evolved from the form of "VV" by 7 to 8 century [22]. The letter $\mathrm{Y}$ in Latin was 
equivalent with Y (upsilon) in Greek, but in English it serves as a short I or J as in German and Italian. An example, Jod (iodine) in German. The letter Z is equivalent with Greek Z. The transcription of the two alphabets are summarized in Table 1.

Table 1 Transliteration of Greek and Latin Letters

\begin{tabular}{|c|c|c|}
\hline Greek letters & Latin letters & Examples in English \\
\hline $\mathrm{A} \alpha$ & $\mathrm{A} \mathrm{a}$ & art \\
\hline $\mathrm{B} \beta$ & $\mathrm{B} \mathrm{b}$ & bottom \\
\hline$\Gamma \gamma$ & Gg & goal \\
\hline$\Delta \delta$ & $\mathrm{Dd}$ & determine \\
\hline $\mathrm{E} \varepsilon$ & E e & editor \\
\hline $\mathrm{Z} \zeta$ & $\mathrm{Zz}$ & zebra \\
\hline $\mathrm{H} \eta$ & E e & editor \\
\hline$\Theta \theta$ & TH th & think \\
\hline $\mathrm{I}_{\mathrm{l}}$ & I i & Italy \\
\hline $\mathrm{K} \kappa$ & $\mathrm{K} \mathrm{k}$ & kite \\
\hline$\Lambda \lambda$ & $\mathrm{L} \mathrm{l}$ & lamb \\
\hline $\mathrm{M \mu}$ & $\mathrm{M} \mathrm{m}$ & mouse \\
\hline $\mathrm{Nv}$ & $\mathrm{Nn}$ & news \\
\hline$\Xi \xi$ & $\mathrm{Xx}$ & xenophobia \\
\hline$\notin 1$ & $\mathrm{Oo}$ & oh \\
\hline$\Pi \pi$ & $\mathrm{Pp}$ & potential \\
\hline $\mathrm{P} \rho$ & $\mathrm{R} \mathrm{r}$ & root \\
\hline$\Sigma \sigma$ & $\mathrm{S} \mathrm{s}$ & seat \\
\hline $\mathrm{T} \tau$ & $\mathrm{Tt}$ & talent \\
\hline Yu & $\mathrm{Uu}$ & put \\
\hline$\Phi \phi$ & PH ph & philosophy \\
\hline $\mathrm{Xx}$ & $\mathrm{CH}$ ch $(\mathrm{KH}, \mathrm{kh})$ & mitochondrion \\
\hline$\Psi \psi$ & PS, ps & psychology \\
\hline$\wedge\rceil$ & $\mathrm{O}, \mathrm{o}$ & cost \\
\hline
\end{tabular}

\subsection{Transcription of Cyrillic Alphabet to Latin Alphabet}

In the Russian alphabet table, four letters are formed by short I+ vowel. The letter "ë"was placed after "e". They are pronounced like "ye "as in yeah and "yo" in yogurt, respectively. The last two letters on the table, "Ю" and " $Я$ " are formed in the same way. The letter equivalent with Greek $\Theta$, $\theta$ was disused in the beginning of the 20th century (circa 1917). A letter "W" was placed before "Z", with pronunciation of "s" as in "pleasure". Similar with Latin, a short I ( й) was placed after "и". In Serbian alphabet, the short I is a non-Slavic "J", while in Ukrainian, the letter "I" is used. From K to $\mathrm{U}$, the letters were the same as Latin, except for the absence of "Q". After $\mathrm{U}$, a letter the same as

Greek " $F$ " was followed, then " $X$ " as the Greek X. The next four letters are not found in the Greek alphabet: Ц ц(tse); Ч ч(che); Ш ш(she) like sh in ship, and, -Щ щ (shch) like shch in Khrushchev.

Russian language is characterized with switch of consonant from hard to soft, and vice versa. The phonetic change is marked with signs of " $\mathrm{b}$ " (soft) and " $\mathrm{b}$ "(soft). The two sings are placed after the letter "ы" which functions as a short "й"; but unlike "й", the letter is not placed in the beginning of words. Before the alphabet table ends with two letters with the combination of short i+vowel, that, "Ю"sounds like "you", and "Я" also means "I"in Russian; The pronouns "I" sound similarly in Russian, "Я"and in Swedish, "Jag" . Together with "Ё"the letters "ы” and "Э” are absent in Bulgarian alphabet.

Currently European Union (EU) has 28 member states, including a number of Catholic Slavic countries like Poland, Slovakia and Slovenia. Twenty four official languages are used in this multinational political and economic union[12; 13]. With the admission of Bulgaria as a member on 1 
January 2007, Cyrillic alphabet becomes the official script ever since; other Slavic member states use Latin alphabet mainly because of the religious reason in the history. After the publication of current orthography in 1945, the Bulgarian alphabet includes 30 letters [13; 14], with absence of the Russian “Ё”, “ы” and “Э” (See Table-2).

\subsection{Spread of Cyrillic alphabet to non-Slavic area}

After Cyrillic alphabet was invented as adapted from Greek, it spread to the eastern and southern part of Slavic world. With Orthodox Christianization of the Turkic dwelling along Volga and Urals, and during the era of Soviet Union, when the central Asian states were incorporated as Soviet constituent republics, Arabic script was replaced by Cyrillic in these regions. Examples were Tatar and Chuvash in Urals mountains [10], and Kazakh and Kirghiz in Central Asian. Prior to the downfall of the Soviet Union, Cyrillic alphabet was used throughout the country, except the Baltic and Transcaucasian republics: Estonia, Latvia, Lithuania, Georgia, Armenia and Azerbijian. When the Soviet Union was collapsed in 1991, these places no longer existed in the same sovereignity with Russia, and Cyrillic alphabet became the sole script in the Russian federation according to the Russian Constitution.

Table 2 Transliteration of Cyrillic and Latin Alphabets

\begin{tabular}{|c|c|c|c|}
\hline Cyrillic/Russian & Cyrillic/Bulgarian & Latin & Examples in English \\
\hline $\mathrm{A} \mathrm{a}$ & $\mathrm{A} \mathrm{a}$ & $\mathrm{A} \mathrm{a}$ & art \\
\hline Б б & Б б & $\mathrm{B} \mathrm{b}$ & bill \\
\hline B в & B в & $\mathrm{Vv}$ & voyage \\
\hline$\Gamma \Gamma$ & $\Gamma \Gamma$ & G g & goal \\
\hline Д д & Д д & $\mathrm{Dd}$ & delta \\
\hline $\mathrm{E} \mathrm{e}$ & $\mathrm{E} \mathrm{e}$ & Ye ye & Yeltsin \\
\hline Ë ë & -- -- & Yo yo & yogurt \\
\hline Ж ж & Ж ж & Zh, zh & pleasure \\
\hline 33 & 33 & $\mathrm{Z}, \mathrm{z}$ & zebra \\
\hline И и & И и & $\mathrm{I} \mathrm{i}$ & Ivan \\
\hline Й й & Й й & Yy & young \\
\hline К к & K к & $\mathrm{K} \mathrm{k}$ & keep \\
\hline Л л & Л л & $\mathrm{L} \mathrm{l}$ & list \\
\hline $\mathrm{M}_{\mathrm{M}}$ & $\mathrm{M} \mathrm{M}$ & $\mathrm{M} \mathrm{m}$ & Malta \\
\hline $\mathrm{H} \mathrm{H}$ & $\mathrm{H} \mathrm{H}$ & $\mathrm{Nn}$ & normal \\
\hline $\mathrm{O}$ o & $\mathrm{O}$ o & $\mathrm{O} 0$ & orange \\
\hline$\Pi_{\Pi}$ & $\Pi \Pi$ & $\mathrm{P} \mathrm{p}$ & petroleum \\
\hline $\mathrm{Pp}$ & $\mathrm{Pp}$ & $\mathrm{R} \mathrm{r}$ & roast \\
\hline $\mathrm{Cc}$ & $\mathrm{Cc}$ & S s & $\underline{\text { sit }}$ \\
\hline $\mathrm{T} \mathrm{T}$ & $\mathrm{T} \mathrm{T}$ & $\mathrm{T} \mathrm{t}$ & tea \\
\hline $\mathrm{Yy}$ & Y y & $\mathrm{U} \mathrm{u}$ & put \\
\hline$\Phi \phi$ & $\Phi \phi$ & $\mathrm{Ph} p h$ & phenol \\
\hline $\mathrm{Xx}$ & $\mathrm{Xx}$ & Kh kh & Loch \\
\hline Ц ц & Ц ц & Ts ts & pants \\
\hline Ч ч & Ч ч & Ch ch & cheese \\
\hline Ш ш & Ш Ш & Sh sh & ship \\
\hline Щ щ & Щ щ & Shch, Shch & Khrushchev \\
\hline $\mathrm{b}$ & $\mathrm{b}$ & Hard sign & $\overline{--}$ \\
\hline ы & -- & $\mathrm{y}$ & bloody \\
\hline b & $\mathrm{b}$ & Soft sign & -- \\
\hline Э, Э &,,---- & $\mathrm{E} \mathrm{e}$ & editor \\
\hline Ю, Ю & Ю, Ю & Yoo, yoo & ubiquitous \\
\hline Я Я & Я Я & Ya ya & yard \\
\hline
\end{tabular}

Cyrillic alphabet was also spread to other countries in the Eastern Bloc, for example the former People’s Republic of Mongolia, today's Mongol Ulus. When examining the Cyrillic alphabet, it was 
found that the letter "Э" is closer to the Latin " $E$ " than " $E$ "; it is used more frequently in Mongolian which adopted Cyrillic alphabet in early $20^{\text {th }}$ century. During Qing Dynasty (1644-1911) in China, the Manchurian emperors bore titles as well as reign name in three languages: Manchu, Chinese and Mongolian. “Chong De (崇德\}”, the reign name of Hong Taiji, the founding emperor of Qing Dynasty, was written in Mongolian as Дээд эрдэмт(Deed Erdemt); it originally meant "lofty virtue”( Wesihun Erdemungge) in Manchurian [23, 24]. The transcription between Latin and Cyrillic alphabets is referred to Table 2.

\section{Conclusion}

Since the invention of Phoenician alphabet, it was spread to a vast region in Eurasia and different parts of the world; , and was modified according to the languages that the alphabet writes, and more slight modifications will take place in keeping up with the advance of information technology.

\section{References}

[1] Swedish alphabet - Wikipedia; https://en.wikipedia.org/wiki/Swedish_alphabet Retrieved on 9 June 2018.

[2] Danish orthography. Wikipedia.https://en.wikipedia.org/wiki/Danish_orthography\#Alphabet, Retrieved on 8 June 2018.

[3] Norwegian orthography - Wikipedia. https://en.wikipedia.org/wiki/Norwegian_orthography, Retrieved on 8 June 2018.

[4] Fischer SR. A history of writing. Reaktion Books. 2004: p. 90.

[5] Daniels PT. "The Arabic Writing system". In Owens, Jonathan. The Oxford Handbook of Arabic Linguistics. Oxford University Press. 2013: p. 415.

[6] Ancient Scripts: Aramaic http://www.ancientscripts.com/aramaic.html, Retrieved on 15 June 2018.

[7] Phoenician Alphabet Origin http://www.phoenician.org/alphabet.htm, Retrieved on 15 June 2018.

[8] Poland - Wikipedia https://en.wikipedia.org/wiki/Poland\#Languages; Retrieved 17 June 2018

[9] Comrie, Bernard; Corbett, Greville G. (1 September 2003). The Slavonic Languages. Taylor \& Francis. p. 45. ISBN 978-0-203-21320-9. Retrieved 9 June 2018.

[10] Cyrillic alphabets - Wikipedia https://en.wikipedia.org/wiki/Cyrillic_alphabets\#Chuvash; Retrieved 8 June 2018

[11] Kazakh alphabets - Wikipedia https://en.wikipedia.org/wiki/Kazakh_alphabets; Retrieved 17 June 2018

[12] "A decade of further expansion". Europa web portal. Archived from the original on 15 June 2007. Retrieved 5 June 2018.

[13] "Greece and NATO: a long lasting relationship". Nato.int. Retrieved 6 March 2017.

[14] "Languages in Europe - Official EU Languages". EUROPA web portal. Archived from the original on 2 February 2009. Retrieved 8 June 2018.

[15] Bulgarian alphabet - Wikipedia. https://en.wikipedia.org/wiki/Bulgarian_alphabet, Retrieved 8 June 2018

[16] Cubberley P. "The Slavic Alphabets". In Daniels and Bright, Eds. The World's Writing Systems. Oxford University Press. 1996; ISBN 0-19-507993-0.

[17] Curta F. Southeastern Europe in the middle Ages, 500-1250. Cambridge Medieval Textbooks. 
Cambridge University Press. 2006; pp. 221-222. ISBN 0521815398.

[18] Encyclopædia Britannica, Major alphabets of the world, Cyrillic and Glagolitic alphabets, 2008.

[19] Powell BB. Writing: Theory and History of the Technology of Civilization. Wiley Blackwell. 2009: p. 182. ISBN 978-1405162562.

[20] C - Wikipedia. https://en.wikipedia.org/wiki/C, Retrieved on 9 June 2018.

[21] Runes - Wikipedia https://en.wikipedia.org/wiki/Runes, Retrieved on 9 June 2018.

[22] Why is 'w' pronounced 'double u' rather than 'double v'? : Oxford Dictionaries Online". Oxford dictionaries.com. Retrieved 8 June 2018.

[23] Wilkinson, E. Chinese History: A New Manual. Cambridge, MA: Harvard University Asia Center. 2012. ISBN 978-0-674-06715-8.

[24] Hong Taiji - Wikipedia https://en.wikipedia.org/wiki/Hong_Taiji; Retrieved 8 June 2018 
